\title{
Rituales y "fetiches" políticos en Chile colonial: entre el sello de la Audiencia y el pendón del Cabildo ${ }^{1}$
}

Jaime Valenzuela Márquez

Universidad Católica de Chile

La legitimación festiva del sistema de poder colonial contaba en el Nuevo Mundo con dos aliados simbólicos fundamentales, dos objetos que representaban directamente al monarca y que, por ese mismo hecho, eran recargados de majestuosidad y rodeados de veneración. El sello y el pendón reales se constituían así en soportes de su presencia intangible, pero ubicua, en todos los rincones del imperio a través de su panoplia litúrgica y, específicamente, gracias a estos objetos singulares. Transformados, a través de un ceremonial sacro/profano apropiado, en verdaderos "fetiches" —al encarnar la "omnipresencia" del soberano, cual transubstanciación divina-, ambos objetos cumplirán su rol político a través de estrategias rituales diferentes, pero complementarias, en el seno de las representaciones mentales colectivas de la sociedad colonial.

Por su parte, los representantes vicarios del soberano y la élite local de Santiago van a aprovecharse ampliamente de la existencia de estos objetos y de la "sacralidad" con que estaban recargados. Al gozar de la exclusividad de su manipulación, estos actores sociales del poder reforzarán su prestigio individual y los lugares privilegiados reservados a sus instituciones al interior del sistema.

\section{Una gran "presencia" en Santiago}

El primer objeto de nuestro análisis corresponde al sello real, un símbolo tradicional de la justicia superior del monarca, quien lo estampaba originalmente al pie de cada documento firmado de su mano. La expansión de la colonización y la necesidad de proyectar la soberanía real sobre los territorios de ultramar implicó la extensión metafórica de la aplicación directa de dicha justicia, a través de la proliferación de los tribunales de Real Audiencia que se instalaron progresivamente en ciudades importantes y/o estratégicas del Nuevo Mundo. Cada uno de estos tribunales disponía de uno de estos sellos, fabricado en plata. Al estamparlo al pie de sus resoluciones éstas tenían validez como si fueran emanadas de la mano del propio soberano, como lo había estipulado explícitamente Carlos V. ${ }^{2}$

1 Comunicación presentada al $49^{\circ}$ Congreso Internacional de Americanistas, Quito (Ecuador), junio de 1997.

2 Véanse las Nuevas Leyes de Indias dictadas por Carlos V en noviembre de 1542, así como la ordenanza de audiencias dictada por Felipe II en octubre de 1563, citadas en Ayala, Manuel Josef de: Diccionario de gobierno y legislación de Indias, publicado en la Colección de documentos inéditos para la historia de Iberoamérica, Madrid, 1929, II, págs. 3-5. Ver también Góngora, Mario: El Estado en el derecho indiano. Época de fundación, 1492-1570, Santiago, Chile, 1951, pág. 64. 
Sin duda, la frase "Yo el rey", escrita al lado de dicho sello, confirmaba la "presencia" de la suprema autoridad y evidenciaba la relatividad del poder ejercido localmente por dichos tribunales, rescatando su origen peninsular. Esta constatación era esencial para fortalecer el cumplimiento de la voluntad real y la extensión de su dominio en territorios lejanos. Sin embargo, el rol simbólico asignado a dicho sello así como a los magistrados u oidores que lo utilizaban, en tanto que representantes personales de dicha justicia real, revestía a la institución con una solemnidad especial que se revelaba con un peso propio en el imaginario local.

El sello, en ese sentido, actuaba como un catalizador esencial. En el caso de Chile, fue en 1609 cuando dicha proyección persuasiva adquirió toda su importancia, en el momento de instalarse la Audiencia en Santiago ${ }^{3}$

3 Este tribunal superior ya había tenido un primer establecimiento en Chile entre 1567 y 1575 , en la ciudad de Concepción, que había asumido una función paralela y de importancia creciente frente a la capital oficial del "reino". En efecto, desde el siglo XVI dicha ciudad era el centro de atención política y militar dada su proximidad a la zona de guerra contra los indígenas mapuches del sur. De hecho, allí habitaba el gobernador chileno durante la mayor parte de su mandato. Durante el siglo XVII esta situación se modificará raramente, pues la capital de la frontera del sur será generalmente el destino inicial de cada nuevo gobernador, quien llegará con refuerzos desde España o Lima y se instalará allí con su familia y, como en el caso de Martín de Mujica, en 1646, "con mucho acompañamiento de criados muy lucidos, y nobles". En este mismo ejemplo vemos que Mujica es recibido en Concepción por su antecesor, el marqués de Baides, en medio de diversas demostraciones festivas; véase Rosales, Diego de: Historia general del reino de Chile. Flandes indiano, Santiago, 1989, II, pág. 1218; ver también Carvallo y Goyeneche, Vicente: Descripción histórico-geográfica del reino de Chile [1796], en la Colección de historiadores de Chile y de documentos relativos a la historia nacional (en adelante $\mathrm{CHCh}$ ), X, pág. 101, donde apunta: “... hasta fin del siglo anterior [se refiere al siglo XVII] fue esta ciudad [Concepción] el destino de los capitanes jenerales [...]”. En general, los nuevos gobernadores tomaban su cargo en primer lugar — bien provisionalmente- en Concepción, y se quedaban allí el tiempo necesario (algunos meses, un año,...) con el fin de informarse sobre la situación de la guerra y de idear una nueva estrategia. Luego, partían hacia Santiago para tomar posesión oficial de su cargo, sobre todo desde 1609, en que debían asumir paralelamente la presidencia de la refundada Audiencia. En todo caso, después de haber cumplido estos ritos y de haber tratado los asuntos de gobierno más urgentes, retornaban rápidamente a Concepción. Véanse algunos ejemplos en Rosales: Historia general..., I, pág. 608; Pérez García, José: Historia natural, militar, civil y sagrada del reino de Chile en su descubrimiento, conquista, gobierno, población, predicación evangélica, erección de catedrales y pacificación, CHCh, XXIII, págs. 197, 199, 211, 219 y 298; Acta del cabildo del 3 de octubre de 1625, en Actas capitulares del Cabildo de Santiago (en adelante ACS), publicadas en CHCh, primera serie (1558-1705), Santiago, 1898-1915, XXVIII, pág. 307, y Acta del 26 de mayo de 1629, ACS, XXX, pág. 96; Barros Arana, Diego: Historia jeneral de Chile, Santiago, 1884-1902, IV, págs. 200-205; Carta de la Real Audiencia al rey, Santiago, 20 de agosto de 1672: Biblioteca Nacional de Chile, Sala José Toribio Medina, Manuscritos (en adelante BN.Mss), vol. 158, doc. 3182, fjs. 194-196.

La efímera duración de la Real Audiencia en Concepción y el carácter de las críticas que motivaron su término reflejaban claramente el rol asignado/ejercido por el alto tribunal civil y la incongruencia de su presencia en un contexto monopolizado por el mundo militar. Así, según el cronista Diego de Rosales, esta institución fue establecida definitivamente en Santiago, “... por ser allí el mayor concurso de la gente, y estar en tierra donde la paz estaba más de assiento, y las variedades de la tierra de arriba de la Concepción, donde: primero estubo, fue más conveniente su asistencia en esa ciudad, 
y coincidiendo con la consolidación de la primacía de esta ciudad, en tanto que único asentamiento urbano capaz de abrigar el tejido civil del Estado. ${ }^{4}$ El ceremonial de la recepción del sello, junto con el de la instalación del tribunal, se reveló como un evento sacralizador por excelencia. A lo largo de toda la celebración podemos apreciar que fue dicho objeto el que concentró todo un ritual claramente consagratorio.

En este sentido, nos parece interesante la interpretación planteada por David Freedberg. ${ }^{5}$ Analizando la respuesta de un devoto/observador frente a una imagen sagrada, señala que lo importante es que dicho acto se basa en la convicción de la presencia de lo representado más que en la representación en sí. Esta tradición occidental, que podemos encontrarla desde el culto a los iconos bizantinos hasta la religiosidad animista ligada a las máscaras ceremoniales en el África Occidental, plantea una fusión entre signo y significado que caracteriza también las representaciones asociadas a la práctica devocional de la América colonial. Para realizar dicha fusión y adquirir aquel poder, en todo caso, la imagen/objeto debe pasar por un proceso de consagración que le permita superar su simple materialidad. ${ }^{6}$ Ello fue justamente lo que ocurrió durante la recepción del sello real en la capital chilena. De hecho, determinados aspectos y gestos del evento, así como la intención final de persuadir al imaginario colectivo de que en dicho símbolo se encontraba la "presencia" del monarca, nos acercan claramente al dogma de la transubstanciación.

\footnotetext{
y de grandes utilidades, porque como los gobernadores estaban siempre ocupados en la guerra y eran más soldados, que letrados, la justicia no se administraba con la entereza que se debiera ...": (Historia general..., II, pág. 831). En otro documento de la época se informa que “... la [Audiencia] de la Concepción se calló y deshizo como plantada en frontera y cercana a las inquietudes de la guerra y parte para ella no conveniente y para allí y más en los primeros principios de los pocos vecinos que en ellos había pareció demasiada y que allí no tenía la Audiencia qué hacer” (BN.Mss, vol. 125, doc. 2247 , fjs. 117-130). Vicente Carvallo y Goyeneche, por su parte, piensa que este tribunal “... no tenía allí [en Concepción] objeto alguno: todos precisamente eran militares y más le convenía un consejo de guerra que un senado; eran allí tan inútiles las plumas como necesarias las espadas": (Descripción..., CHCh, X, pág. 103).

4 De Ramón, Armando: Historia urbana. Una metodología aplicada, Buenos Aires, 1978, págs. 77 y 178; de este mismo autor: Santiago de Chile (1541-1991). Historia de una sociedad urbana, Madrid, 1992, págs. 41-42; Carvallo y Goyeneche: Descripción..., CHCh, X, págs. 101-102; Errázuriz, Crescente: Historia de Chile durante los gobiernos de García Ramón, Merlo de la Fuente y Jaraquemada, Santiago, 1908, II, pág. 27; Barros Arana: Historia jeneral..., V, pág. 341; Juan, Jorge y Antonio de Ulloa: Relacion historica del viage a la America meridional, Madrid, 1748, III, libr. II, pág. 340.

5 Freedberg, David: El poder de las imágenes. Estudios sobre la historia y la teoría de la respuesta, Madrid, 1992, págs. 46-50.

6 Véanse los artículos "Sacré" y "Anthropologie visuelle", en la obra de Bonte, Pierre e Izard, Michel (dirs.): Dictionnaire de l'ethnologie et de l'anthropologie, París, 1992, págs. 641-642 y 741-742, respectivamente.
} 
Así, si bien los nuevos magistrados actuaron en un primer plano, al lado del gobernador/presidente, era el sello el que se presentaba a los ojos de la población como el símbolo central que les irradiaba la autoridad del monarca lejano pues, según señalaba el propio soberano,

"[...] cuando el nuestro sello entra en cualquiera de las nuestras audiencias reales de estos reinos, entra con la autoridad que si nuestra real persona entrase [...]".?

De ahí que esas autoridades desplegaran para aquella ocasión un tratamiento "fetichista" singular hacia dicho objeto, conscientes de que aquello les revertía con su aura legitimante.

Los flamantes oidores habían llegado desde Lima a fines de abril, pero los preparativos para la fiesta habían comenzado tres meses antes. Aún se tuvo que esperar hasta comienzos de septiembre para que todo estuviera dispuesto y el sello hubiese llegado a la capital. Como era habitual para las grandes ocasiones litúrgicas, correspondía a la municipalidad la organización del evento y ornamentación de la ciudad, así como la convocación de la población. Así, se encarecía el arreglo y embellecimiento de las calles por donde transitaría el cortejo; también se prohibía, so pena de multa, los lutos de particulares, incluso los de la propia élite, a fin de recrear un ambiente de completa alegría y de suspenso de lo cotidiano. Se mandaron hacer vestiduras para los integrantes del cabildo, que sin duda tendrían un lugar privilegiado en esta gran liturgia legitimante del sistema de poder del que formaban parte. Es interesante constatar que el tono sacralizador de la ceremonia ya se veía en su organización, pues el cabildo costeó la fabricación de un suntuoso palio destinado a cubrir el sello a lo largo de su recorrido urbano. ${ }^{8}$

\section{La "sacralización"}

Contamos con una descripción excepcional que nos revela con cierto detalle los diferentes pasos rituales que acompañaron esta ceremonia; pasos orientados a recrear un culto venerativo al sello y que, en todo caso,

7 BN.Mss, vol. 289, doc. 8481, fjs. 60-61: Cédula real enviada a la nueva Audiencia para su instalación en Santiago, 17 de febrero de 1609.

8 Todos estos preparativos endeudaron al cabildo en más de 2.000 pesos, reflejando con ello la importancia que el evento tenía para la élite institucionalizada. Sobre el contexto y las significaciones sociales y políticas que rodeaban este tipo de liturgias públicas en Chile colonial, véase Valenzuela Márquez, Jaime: Liturgies et imaginaire du pouvoir. Fêtes, cérémonies publiques et légitimation politique à Santiago du Chili (1609-1709), Paris, tesis de doctorado, École des Hautes Études en Sciences Sociales, 1998, 2 tomos. 
eran los previstos para todo el imperio en ocasiones similares. ${ }^{9}$ En primer lugar, podemos apreciar que el evento se desarrolló en dos días, igual que las principales fiestas religiosas. Como éstas, el primer día se dedicó a articular determinados ritos característicos de las vísperas, a los que se unieron elementos propios de las recepciones de autoridades vicarias. Así, a la hora prevista, los integrantes de la nueva Audiencia y toda la aristocracia local se dirigieron cabalgando a una casa en las afueras de la ciudad, donde aguardaba el gobernador con el sello; desde allí se organizó el cortejo oficial que acompañó el trayecto hasta los "límites" urbanos. El mensaje simbólico enviado al espectador era bastante claro y reflejaba la intención de persuasión política que alimentaba a este programa ceremonial: el gobernador, en tanto que nuevo presidente del tribunal y, por lo tanto, reforzado en su rol de representante real, monopolizaba el contacto directo con el sello, trayéndolo colgado del pecho y oculto a la vista dentro de una caja dorada.

La "sacralización" del objeto monárquico se hizo evidente de inmediato, pues el cortejo se dirigió directamente al convento de San Francisco - situado en el margen sur de la ciudad - en cuyo interior se había previsto una recámara apropiada para acoger el sello hasta el día siguiente. Toda la comitiva se apeó y desapareció de la vista del público, iniciando el ceremonial privado propio del "tabú" que debía rodear al sello.

El espacio sagrado escogido para este fin tenía, por su parte, un peso indiscutible en el imaginario colectivo, entre otros factores porque allí también se custodiaba otro "fetiche" esencial para la estabilidad de la ciudad: la imagen de Nuestra Señora del Socorro, intercesora singular frente a las catástrofes y, sintomáticamente, una advocación fuertemente ligada al cabildo y al imaginario aristocrático/guerrero en el que fundaba sus orígenes la élite de Santiago.

En efecto, dicha invocación protectora tenía una tradición local de apropiación municipal, que se arraigaba en el voto jurado por el ayunta-

9 El documento lo hemos transcrito integramente en anexo. Ver en general Recopilación de leyes de los reinos de las Indias mandadas imprimir y publicar por la majestad católica del rey don Carlos II nuestro señor, Madrid, 1681 (en adelante RLI), libr. II, tit. 21. La cédula enviada a la nueva Audiencia para su instalación, señalaba explícitamente : “... yo vos mando que tengais cuidado llegado que sea el dicho sello a la dicha provincia de Chile, antes que entre en la dicha Audiencia de Santiago, de salir vosotros y la Justicia y Regimiento de la dicha ciudad un buen trecho fuera de ella a recibir el dicho sello y desde donde estuviere a la dicha ciudad vaya encima de un caballo bien aderezado y vos el presidente y oidor más antiguo lo llevad en medio con toda la veneración que se requiere, segun y como se acostumbra hacer en las audiencias reales de estos reinos y así por esta orden ireis hasta le poner en la casa de la Audiencia real ..." (Real cédula de 17 de febrero de 1609, ya citada). 
miento desde los primeros tiempos de la conquista. Su culto se había establecido a partir de una imagen que habría traído Pedro de Valdivia en persona desde España, y que habría sido custodiada más tarde en el templo de San Francisco. Dicha imagen se constituyó en objeto de culto preferencial del universo de conquistadores hispanos, que construyeron su primera ermita y que fundaron una cofradía reservada a su grupo social. Esta virgen, además, había sido elegida tempranamente también como patrona de las armas españolas implicadas en la conquista de Chile,

“[...] a quien los antiguos pobladores y conquistadores de él tenían en tanta veneración y devoción que se sabe de cierto que ninguno salía de la ciudad para fuera de ella o para la guerra que primero no la visitase y lo mismo de vuelta antes de entrar en sus casas $[\ldots] "{ }^{10}$

La Virgen del Socorro se ligaba, así, a una conciencia de identidad histórica por parte del cabildo y, por lo tanto, de la élite local. Una élite que se esforzaba permanentemente por mostrar su origen en términos de aristocracia guerrera, heredera de los primeros conquistadores. ${ }^{11}$ Su imagen, además, contaba con el poder y la popularidad necesarias para interceder ante la divinidad frente a grandes epidemias o catástrofes telúricas, jugando un rol global y superior al de los santos y vírgenes que actuaban como especialistas de calamidades específicas. Dicho rol se basaba, justamente, en que la Virgen del Socorro actuaba como patrona "de la ciudad" y era

10 Acta del cabildo de 28 de febrero de 1645, ACS, XXXIII, pág. 31. Ver también Guarda, Gabriel: "Formas de devoción en la Edad Media de Chile. La Virgen del Rosario de Valdivia", Historia, 1, Santiago de Chile, 1961, págs. 156-179; RLI, libr. I, tit. I, ley XXIV. La leyenda pretendía, además, que esta imagen portaba una pequeña piedra en su mano derecha desde que, en los primeros tiempos del establecimiento hispano, los indígenas del valle del Mapocho habían atacado lo que en ese momento era el campamento militar de Santiago. La Virgen, en dicho evento, habría apoyado objetivamente la resistencia militar de los conquistadores, encegueciendo a los aborígenes con puñados de arena que habría lanzado a sus ojos. Al respecto, véase Carvallo y Goyeneche: Descripción..., CHCh, X, pág. 41.

11 La renovación de los votos del cabildo a Nuestra Señora del Socorro se encuentra en el acta del 1 de agosto de 1667, ACS, XXXVII, págs. 187-194. En dicha ocasión, la municipalidad recordaba también al convento franciscano la obligación recíproca que implicaba este voto : la celebración de una misa dedicada a dicha Virgen todos los sábados “... por la intención de los antepasados y presentes capitulares deste cabildo y de los que en adelante fueren". En este acta se transcribió, a fin de reforzar la historicidad del compromiso, lo que se había acordado en la sesión del 17 de marzo de 1554 -firmada por "los muy magníficos señores justicia y regidores desta dicha ciudad"- que había instaurado originalmente el voto institucional. En dicha ocasión se había contado con la presencia del comisario de la orden franciscana y del mayordomo de la cofradía, este último perteneciente, por supuesto, al grupo de notables de la ciudad. Ver también el acta de 2 de septiembre de 1667, ACS, XXXVII, pág. 197. 
"auspiciada" de forma institucional por el propio municipio. Actuaba sola o apoyando a los santos respectivos. ${ }^{12}$

De este modo, la primera fase de la "sacralización" del "fetiche" monárquico iba a realizarse al interior de un espacio que, además de un contexto intrínsecamente sagrado, ofrecía, implícitamente, la perspectiva de ligar el símbolo real a dicha imagen tutelar. La habitación destinada a recibirlo, adornada con solemnidad, hacía resaltar un ambiente imponente donde, bajo un dosel —decoración que normalmente estaba dispuesta sobre los asientos de los obispos y de las principales autoridades políticas- se había elevado un pequeño estrado con un bufete. Sobre él, en medio de cojines y sedas, el gobernador y el oidor decano, incados en evidente actitud adorativa, colocaron el cofrecito "sagrado". Encima de éste se colocó una corona de plata dorada, de la cual no existe cuenta en el Cabildo, por lo que quizás provendría de alguna de las imágenes mariales (por qué no de la propia Virgen del Socorro?).

Aquí se dio por terminada esta primera fase litúrgica de la recepción del sello. La comitiva procedió a retirarse, salvo el oidor decano, que protagonizó la segunda fase de sacralización: la vigilia. Acompañado de un secretario, encargado de dar el correspondiente testimonio de la labor cumplida, la autoridad se quedó junto al pequeño santuario monárquico toda la noche.

\section{La entrada oficial del "fetiche-tabú"}

El día siguiente, que coincidió sintomáticamente con una fiesta religiosa tan importante como la Natividad de la Virgen, fue el de la entrada oficial del sello, ya "sacralizado", a la ciudad. El cortejo adquirió allí todo el esplendor de las grandes celebraciones, componiéndose de todas las autoridades civiles y religiosas, desde el gobernador hasta los capitulares, el clero secular y regular de la ciudad, así como el conjunto de la élite, todos pomposamente vestidos. El día anterior no habría revestido el mismo despliegue, seguramente, porque no correspondía al día principal de las celebraciones y por el poco espacio de exhibición pública que se les re-

12 A finales del siglo XVIII, Carvallo y Goyeneche confirmaba la larga duración de esta tradición: "La ciudad, en sus angustias y públicas necesidades, ocurre a la protección [de dicha Virgen] en cuerpo de ayuntamiento, y hasta ahora no se ha dado ejemplar de no haber sido bien despachadas sus humildes súplicas": (Descripción histórico-geográfica..., CHCh, X, pág. 41). 
servó a los participantes, por haber estado el cortejo limitado a las afueras de la ciudad. De hecho, la "coincidencia" con la festividad marial permitió acrecentar el lucimiento y reforzar el ambiente "sagrado" que debía envolver a todos estos actores, pues — según nos informa otro cronista— la misma comitiva, antes de dirigirse a buscar el sello al convento de los franciscanos, participó en la celebración de la "misa y fiesta" llevada a cabo anualmente en el convento de los mercedarios. ${ }^{13}$

Una vez llegado adonde esperaba el sello, el cortejo se apeó y parte de él ingresó hasta la recámara. Allí tuvo lugar un nuevo rito de veneración por parte de las principales autoridades. Los gestos fueron ahora más numerosos y significativos que el día anterior. Además de arrodillarse ante el cofre, el oidor decano procedió a abrirlo y a extraer el precioso objeto. El gobernador y el propio obispo, así como el conjunto de oidores y los alcaldes del cabildo procedieron a besarlo y a colocarlo sobre sus cabezas, en señal del poder superior que portaba dicho símbolo. Después de guardarlo en su cofre, fue llevado bajo palio desde la recámara hasta la salida del convento, tal como si de una procesión religiosa se tratase. De hecho, la comunidad franciscana en pleno, con cruces y vestimentas litúrgicas, formó parte de este acompañamiento. Afuera, esperaba el resto de la comitiva y un caballo lujosamente adornado destinado a portarlo.

A la vista pública, el juego misterioso se acentuó, pues el cofre dispuesto sobre el caballo fue a su vez cubierto con bandas de género, cuyos extremos eran sostenidos por el gobernador y el oidor decano. Estos últimos se transformaban así en los protagonistas más cercanos al "fetiche". Por lo demás, conforme a la propia disposición real, estas autoridades debían ubicar el caballo del sello en medio de ellos y acompañarlo "[...] con toda la veneración que se requiere [...]". ${ }^{14}$ El juego de sacralidad se acentuaba también puesto que, cual cortejo del Corpus Christi, dicho caballo iba cubierto por el palio confeccionado por el cabildo. No nos debe extrañar, por lo mismo, que fuera esta institución en pleno la que se encargara de llevar las varas que lo sostenían durante el trayecto entre el convento franciscano y la plaza mayor. La élite municipal también jugaba, de esta manera, un papel protagonista, insertándose en el límite interior del círculo privilegiado que rodea-

13 Rosales: Historia general..., II, pág. 832.

14 BN.Mss, vol. 289, doc. 8481, fjs. 60-61, passim: Cédula de 17 de febrero de 1609, cuando se recibió el sello en Concepción, en agosto de 1567, en el momento de la instalación de la primera Audiencia en el reino, el cabildo de dicha ciudad también había adquirido y engalanado un costoso caballo para transportarlo (Carvallo y Goyeneche: Descripción histórico-geográfica..., CHCh, VIII, pág. 164). 
ba al fetiche monárquico. Otros dos oidores, por su parte, iban delante del caballo, tirando de otras bandas de tela que se descolgaban de él. Según deja entender la descripción del evento, delante de este núcleo central iba "[...] grande infinidad de gente [...]", entre los que se contaba el obispo y su cabildo eclesiástico, así como el clero regular de la ciudad. ${ }^{15}$ Así, todo lo que rodeaba al "fetiche" oculto correspondía al espectáculo ofrecido por el sistema de poder local, que se beneficiaba y nutría del símbolo real según el lugar ocupado por cada actor, de su cercanía al objeto, etcétera.

Interesa en particular subrayar el hecho de que la vanguardia de toda esta estructura móvil estaba encabezada por el otro símbolo de la presencia monárquica —el pendón-y por cinco compañías de milicias, acompañamiento característico en estos años de tensión bélica en el sur del reino. Estos civiles militarizados aportaron una solemnidad marcial al desfile, acentuado por el ruido de sus instrumentos musicales y las descargas de su armamento, con lo que, "[...] yendo en prosesion y orden de guerra, se fue marchando hasta llegar á las casas reales [...]". ${ }^{16} \mathrm{Al}$ mismo tiempo, sus integrantes se beneficiaban del lucimiento personal que les brindaba su integración espectacular al evento. De hecho, al llegar a la plaza, decorada como era habitual para las grandes ocasiones, fueron estas compañías las encargadas de disponer el espacio de tal forma que el cortejo circulara entre ellas durante el último tramo que debía atravesar hasta el edificio de la Audiencia.

Al llegar a su destino, el sello venía impregnado no sólo con la "sacralización" previa, sino también con toda la admiración y el aura misteriosa que había recogido a lo largo de su trayecto, oculto siempre a la vista de la gente común en su cofre y rodeado de toda la pompa que ensalzaba su rol político, su proyección fetichista en el imaginario colectivo, en fin, la presencia transubstanciada del propio soberano.

La fase siguiente retomaba el aparato ritual que había caracterizado la sacralización privada escenificada en el convento franciscano: el símbolo monárquico entró en el edificio, pasando así a alimentar con su carga sagrada el interior de la sede que albergaba a una de las instituciones vicarias fundamentales de la Corona, alimentando su legitimidad en el plano esencial de la subjetividad.

Su característica de "fetiche" misterioso, por otra parte, formaba parte de la esencia de su estrategia simbólica permanente. De hecho, fuera de la recepción de este primer sello, las fuentes no registran otra similar, lo que es

15 Véase el documento anexo.

16 Ibídem. 
sintomático si consideramos que, con cada nuevo monarca que ascendía al trono, se enviaba uno con las nuevas armas que debía reemplazar al sello del rey difunto. Al parecer, este momento era vivido como un acto más o menos administrativo, con una breve ceremonia privada limitada al tribunal. Lo común a lo largo del período colonial fue, por lo tanto, la ausencia de celebraciones públicas orientadas específicamente a este objeto simbólico.

Por otra parte, sólo tenían acceso a la manipulación de este singular "tabú" los miembros de la Audiencia —especialmente el canciller, que guardaba la llave del cofre-, en el momento de emitir una resolución. El privilegio de verlo se extendía a otros funcionarios principales, a miembros del cabildo y al resto de patricios locales en las ocasiones en que se recibía a un nuevo gobernador u oidor. En estos casos, la norma imponía que antes de aceptarlos oficialmente en el seno de la institución — como presidente o como magistrado, respectivamente- se debía cotejar el sello que traía la cédula de nombramiento con la matriz que guardaba el tribunal local. Es interesante subrayar el lugar central que volvía a ocupar la élite municipal en estos rituales esporádicos, pues no sólo tenía derecho a sentarse en la sala de la Audiencia, sino también a acompañar la traída del sello desde la recámara donde se guardaba hasta la sala y su posterior retorno una vez efectuado el rito de cotejo. ${ }^{17}$

En el caso de un nuevo presidente, esta ceremonia interna contrastaba con su juramento público como gobernador, realizado momentos antes en las "puertas" de la ciudad. Era una ceremonia semi-privada, a la que sólo tenían acceso los privilegiados de siempre, los actores tradicionales del poder local, mientras que el resto de la sociedad aguardaba en la plaza, consciente de la discriminación lógica que aquel objeto misterioso y poderoso reservaba a un círculo exclusivo de elegidos. Era en esta discriminación en donde el sistema marcaba los grandes espacios metafóricos que separaban jerárquicamente a los actores del poder del resto de la comunidad. Paralelamente, este ocultamiento premeditado de uno de los símbolos fundamentales de la monarquía jugaba con una fórmula clásica de la religiosidad dominante - por ejemplo, la hostia consagrada, oculta a la vista profana la mayor parte del año-. Por la vía del misterio, la "sensación" colectiva respecto a la sacralidad del sello real podía fácilmente unirse a las de respeto y temor por lo desconocido, en el marco del poder evidente y objetivo que ejercía el tribunal que lo guardaba.

17 Acta del cabildo de 21 de marzo de 1686, ACS, XLII, pág. 121. 


\section{Una estrategia diferente para el estandarte real}

En contraste con este ocultamiento premeditado y permanente, y siguiendo el juego barroco de contradicciones tan caro a la época, existía otro objeto que también representaba la soberanía del monarca y su omnipresencia en sus colonias, pero mediante una estrategia completamente diferente: la del lucimiento público y ostentoso, la de la exposición regular y relativamente frecuente ante los ojos de los súbditos locales. El pendón o estandarte real, si bien portaba una representación similar a la del sello, se constituyó en el símbolo monárquico más común en América. Ello no sólo por su mayor presencia en el espacio público, sino y sobre todo porque debía encontrarse en prácticamente todas las ciudades del "Nuevo Mundo", a diferencia del sello, que únicamente estaba donde había Audiencia. Además, era un objeto que tenía una larga tradición como símbolo del poder monárquico en Castilla ya desde el siglo XII, como lo testimonian miniaturas de la época. ${ }^{18}$

Finalmente, hay que tener en cuenta que, a nivel local, el pendón se había integrado al imaginario político medio siglo antes que el sello. La primera vez que se le menciona en las fuentes de la capital chilena es justamente en 1556, cuando la llegada de la cédula que concedía las armas de la ciudad, un evento que marca también, sintomáticamente, el establecimiento de la fiesta anual al apóstol Santiago. ${ }^{19}$ Esta larga tradición, unida a su vocación de símbolo "público" de la soberanía real, le daban un peso distinto en la alimentación de la legitimidad del sistema político, frente a la privacidad misteriosa con que apareció revestido el sello en el siglo XVII.

De hecho, la frecuencia de su exposición pública comenzaba por la más aleatoria y espaciada en el tiempo, aunque también la más importante en relación a los objetivos adscritos a dicho símbolo: el pendón encabezaba las principales ceremonias de la monarquía, especialmente las procla-

18 Rucquoi, Adeline: "De los reyes que no son taumaturgos: los fundamentos de la realeza en España”, Relaciones, 51, El Colegio de Michoacán, Zamora, 1992, pág. 77.

19 El cabildo nombró para la ocasión al primer alférez real, encargándole la fabricación de un estandarte en seda carmesí (Actas del cabildo de 23 y 24 de julio de 1556, citadas en González, Julio: "Santiago apóstol y el paseo del estandarte real en Chile", Boletín de la Academia Chilena de la Historia, Santiago, 52, 1955, págs. 136-137. Cf. también Carvallo y Goyeneche: Descripción histórico-geográfica..., CHCh, X, pág. 36). En todo caso, será dos años más tarde, con motivo de la primera proclamación real efectuada en Santiago — por Felipe II-, que cuando el municipio confecciona un pendón oficial y permanente, en damasco azul, donde se podían ver bordadas por un lado las armas de la monarquía y por el otro las de la ciudad (Acta del cabildo de 15 de abril de 1558, ACS, XVII, págs. 11 y 19). 
maciones reales. En estas ocasiones, era este objeto el que centralizaba los gestos y ritos "entronizantes", así como los gestos de fidelidad de los súbditos. En efecto, el día de la proclamación de un nuevo monarca comenzaba con la constitución del cortejo oficial que "oficiaría" la ceremonia y que incluía a las principales autoridades civiles y a los notables del municipio. El grupo se dirigía a caballo y en orden jerárquico hasta la casa del alférez real, donde se guardaba el estandarte. Luego de haber incorporado al símbolo y al que lo custodiaba, y siempre con el rigor ceremonial requerido, el cortejo avanzaba hasta la plaza mayor, donde unos días antes se había construido un rústico estrado. Desde la mañana temprano la oligarquía local, tanto la de la ciudad como la que venía para la ocasión desde la comarca cercana, se había instalado alrededor de esta construcción efímera, así como los batallones de milicias más importantes, los gremios de artesanos y la masa de espectadores, convocados por el bando municipal previamente publicado.

Las principales autoridades subían al podio y se procedía entonces a la lectura en voz alta de la cédula real que anunciaba el acontecimiento. Luego, el documento pasaba por las manos de cada actor político, que lo colocaba sobre su cabeza en signo de acatamiento. Los ritos que seguían a continuación se centraban en el estandarte real, objeto que encarnaba en ese momento y ante la mirada pública el juego simbólico de cambio/continuidad de la cabeza del sistema de poder imperante. En un gesto de fidelidad evidente, el estandarte era besado por cada uno de los personajes que se encontraban sobre el estrado, incados y con sus cabezas descubiertas. ${ }^{20}$ Acto seguido, tenía lugar el rito más importante: el juramento público de fidelidad y la aclamación del nuevo rey. El gobernador o su representante tomaba el estandarte de las manos del alférez y gritaba una frase más o menos estereotipada en todo el imperio. Para la aclamación de Felipe IV, por ejemplo, se gritó: "Castilla y León y el reino de Chile y sus provincias por el rey don Felipe, nuestro señor, cuarto de este nombre [...]". El gobernador repetía esta fórmula tres veces desde diversos ángulos del estrado, al

20 La primera vez que un nuevo monarca fue proclamado en Santiago — se trataba de Felipe II-, “... estando el dicho Pedro de Miranda [el alférez real] parado con el dicho pendón [sobre el podium], el dicho señor Justicia Mayor é los dichos señores del Cabildo é los demás desuso referidos [funcionarios diversos y autoridades eclesiásticas], por su orden, con sus gorras quitadas, llegaron donde estaba el dicho alférez con el dicho pendón, é las rodillas hincadas en el suelo, tomaron el canto postrero del dicho estandarte real, lo besaron é pusieron sobre su cabeza, como estandarte é bandera de su rey é señor natural, y en señal del reconocimiento debido" (Acta del cabildo de 17 de abril de 1558, ACS, XVII, passim). 
mismo tiempo que batía el pendón con energía. Este gesto, que oficializaba el "coronamiento" metafórico del rey virtual en la colonia, era acompañado por los gritos y vivas de aprobación —inducidos, evidentemente, desde el podio - de la masa de espectadores y por los disparos de la milicia, considerados como el gesto indudable del juramento colectivo de fidelidad al "señor natural". ${ }^{21}$ Los gritos y disparos continuaban durante la etapa siguiente, en la que los actores principales volvían a montar y, junto al resto de la oligarquía asistente, llevaban a cabo una serie de cabalgadas triunfales por las calles de la ciudad, encabezadas por el estandarte y su alférez real y por el representante vicario del monarca.

En este mismo sentido, conforme a la representación que encarna, el pendón ocupa un lugar privilegiado en las liturgias legitimantes del poder local. Encabeza, por supuesto, las principales ceremonias ligadas a la recepción de autoridades vicariales. Para las recepciones de nuevos gobernadores, por ejemplo, luego de su "entrada" a la ciudad, a caballo y seguido del resto de actores políticos, la nueva autoridad avanzaba por la "calle del Rey" en medio de un desfile que iba encabezado por dicho símbolo portado por el alférez real. Este papel privilegiado constituía el signo evidente del peso superior que debía tener la soberanía de la monarquía lejana, fuente de todo poder político en el "Nuevo Mundo", pese a la magnificencia personificada en la nueva autoridad vicaria. El pendón traspasaba a esta última, de esta forma, la evidencia irrebatible de la fuente originaria de su poder, a través del contacto visual — confusión en el mismo espacio que

21 El acto de izar y arbolar el pendón real era un rito fundamental, llevado a cabo en todas las concentraciones urbanas del imperio español. Su manipulación ritual en estas ocasiones se insertaba en el juego metafórico del "renacimiento" de la monarquía. Por lo demás, vemos ritos similares en el caso de los funerales reales franceses. En este caso, por ejemplo, se bajaba el estandarte frente al féretro del soberano fallecido, procediendo de inmediato a izarlo nuevamente con energía, simbolizando con ello la llegada sin interrupción de su sucesor. Al respecto, véanse los conocidos estudios de Kantorowicz, Ernst: Los dos cuerpos del rey. Un estudio de teología política medieval, Madrid, 1985, págs. 385-392, y de Giesey, Robert: Cérémonial et puissance souveraine. France, XVe-XVIIe siècles, Paris, 1987, pág. 30. Podemos observar la misma fórmula para la coronación de Carlos V, en Bruselas, en 1516; véase Varela, Javier: La muerte del rey. El ceremonial funerario de la monarquía española (1500-1885), Madrid, 1990, págs. 59-61. La ceremonia de "izar pendones" por el rey era una tradición de la Castilla medieval. Tuvo lugar por primera vez en honor de Enrique de Trastamara, en 1366; véase, al respecto, Rucquoi, Adeline: Histoire médiévale de la Péninsule ibérique, Paris, 1993, pág. 327. Ver también Solano, Francisco: Las voces de la ciudad. México a través de sus impresos (1539-1821), Madrid, 1994, pág. XLIX, que recuerda, en todo caso, que en Castilla nunca hubo una ceremonia específica para la coronación real, sino sólo un acto público de juramento en que el soberano se comprometía a respetar ciertas costumbres y fueros tradicionales. Después de este discurso seguía de inmediato el rito de izamiento del estandarte y la aclamación colectiva por parte de los súbditos reunidos en lugares específicos de la ciudad. 
focalizaba el evento, similitud de telas y colores decorativos...- - y a través de los gestos rituales explícitos que efectuaba el personaje frente a dicho objeto - arrodillarse y jurar el cargo, por ejemplo, o, en el caso de la proclamación de un nuevo monarca, el gesto de besar directamente el estandarte, como acto de sumisión-.22

De acuerdo a su estrategia de exhibición pública generalizada, el pendón encabezará también las principales celebraciones que se llevarán a cabo en el espacio público, tanto en el plano civil como en el religioso - como, por ejemplo, la procesión principal de Corpus Cristi-. Incluso, en situaciones de emergencia bélica en el sur, será utilizado, conforme a la antigua tradición medieval, para convocar en la plaza mayor al reclutamiento de voluntarios: una apelación a la fidelidad de los súbditos en torno a un sentimiento/símbolo común, que se conjugaba muy bien con la fuerza emotiva que emanaba de dicho estandarte. ${ }^{23}$

En todas las situaciones anteriores, el pendón asume plenamente su rol de símbolo de la soberanía real, de materializador de la cabeza suprema del poder, paternal y autoritaria; un objeto, enfin, que se presenta frecuentemente a los ojos de la población como referente común en el proceso de su unificación mística en torno a la figura monárquica.

El símbolo del rey imaginario, con su exhibición en primer plano, actúa efectivamente, de esta manera, en la lógica de la retroalimentación legitimante del sistema de poder. Su presencia en los principales eventos permite irradiarlos con la imagen poderosa que representa, lo mismo que a los principales actores políticos locales que siempre están próximos a él y que participan del privilegio de manipularlo a la vista pública. Por extensión lógica, el símbolo real proyecta, así, dicha legitimación al conjunto de mecanismos de dominación que están implícitos en el posicionamiento político y en los roles de poder asumidos por cada uno de dichos actores.

En contrapartida, el pendón — y el monarca que representa - obtiene la legitimación de su función simbólica al ser revestida de actos ceremo-

22 En 1568, por ejemplo, para la recepción del nuevo gobernador Melchor Bravo de Saravia, la municipalidad ordenó disponer el habitual dosel para la jura ritual que se llevaría a cabo en la entrada a la ciudad. El material utilizado fue una tela de damasco azul, con flecaduras de seda y oro, igual al que había servido para fabricar el estandarte que se instalaría a su lado en el momento de la ceremonia : una ligazón cromática más, orientada, como otras, a la visualización de una comunión de poder entre el Rey/pendón y su vicario. Luego, en el momento del cumplimiento de los gestos rituales, se marcarían las necesarias jerarquías entre ambos "actores", a fin de evidenciar también el equilibrio que regía dicha comunión (Acta del cabildo de 16 de agosto de 1568, ACS, XVII, págs. 243 y ss).

23 Ver, por ejemplo, Rosales: Historia general..., II, pág. 1049; Acta del cabildo de 2 de marzo de 1655, ACS, XXXV, pág. 28. 
niales específicos, de gestos de sumisión explícitos por parte de dichos actores y, enfin, de ritos claramente "sacralizadores".

\section{¿Fiesta de Santiago o del pendón?: un juego de sacralizaciones al interior del sistema}

Esta legitimación, con la que frecuentemente se recargaba el pendón, tenía un acento especial y una regularidad que aumentaba su importancia —en relación al resto de liturgias cívicas, generalmente aleatorias y esporádicas-, en la fiesta que anualmente se le dedicaba.

La costumbre y la ley habían estipulado desde los primeros tiempos de la conquista que el estandarte real debía ser paseado solemnemente por las calles importantes de cada ciudad americana una vez al año, en compañía de los principales vicarios del monarca y de la aristocracia local, todos vestidos y engalanados como para las grandes celebraciones del sistema. Lo interesante de recalcar es que la ocasión no sólo se veía revestida de importancia por este rito eminentemente cívico, sino y sobre todo porque el día escogido debía coincidir preferentemente con la fiesta religiosa del santo patrono de la ciudad o con el aniversario de su fundación. En este sentido, el modelo para las colonias periféricas como la chilena provenía de las capitales virreinales, según lo establecía la disposición dictada en 1530 por Carlos V: en Lima el paseo del pendón se realizaba el día de Pascua de Reyes, mientras que en México era en la fiesta de San Hipólito. ${ }^{24}$

Asistimos así a una nueva manifestación de la tradicional imbricación de liturgias políticas y eclesiásticas, orientada a la legitimación del sistema. Con ello, el evento adquiría una dimensión sacralizante especial, que iba mucho más allá del simple "paseo" y se transformaba en una verdadera fiesta cívico-religiosa. Siguiendo esta norma, en Santiago se realizaba cada año el día de la fiesta del apóstol Santiago ( 25 de julio). ${ }^{25}$ Además, como en

24 Véase RLI, libr. III, tit. 15, ley LVI. Para México, véanse las descripciones transcritas en Bayle, Constantino: Los Cabildos seculares en la América española, Madrid, 1952, págs. 661-663. Este mismo autor transcribe la disposición dictada por el virrey del Perú en 1702 para la celebración de dicho evento en Buenos Aires, durante la víspera y el día de San Martín, patrón de la ciudad (págs. 665-666).

25 Cf. para Santiago, Pérez García: Historia natural..., CHCh, XXII, pág. 166. Carvallo y Goyeneche, en su Descripción..., CHCh, X, pág. 69, señala que en su época (a fines del siglo XVIII) en La Serena -norte de Chile-, fundada el 15 de noviembre de 1543, el pendón era paseado la víspera y el día de San Bartolomé, patrón del villorrio, “... procurando imitar en lo posible a la capital del reino en la grandeza y majestad de la función”. Luego, este autor nos informa que ocurría algo similar en San Agustín de Talca -en el centro del país-, fundado el 17 de febrero de 1742 (Ibídem, 
toda fiesta religiosa principal, dicho paseo se efectuaba también el día previo, asociándose así a la vísperas canónicas del santo.

Cabe subrayar la importancia que adquiere a nivel local la articulación del ceremonial anual previsto para dicho objeto en el contexto de la celebración de este apóstol tan singular. Sin duda, al observar que Santiago era el patrón de muchas de las ciudades americanas, la situación vivida en Chile podría ser bastante común, sobre todo si abordamos dicha fiesta como una estrategia de unificación simbólica del imperio colonial en torno a la personalidad fuerte de un santo ligado íntimamente a la monarquía hispana. ${ }^{26} \mathrm{Sin}$ embargo, si tomamos en cuenta el imaginario identitario que predominaba entre el sector aristocrático de la capital chilena y que fundamentaba una parte esencial de su prestigio, podemos deducir que dicha fusión litúrgica iba más allá de la coincidencia con la fiesta del patrono local. El apóstol Santiago se caracterizaba por ciertos elementos propios que se ajustaban perfectamente a la significación persuasiva que se le quería otorgar al pendón y a la fuerza de su sacralización. En este mismo sentido, la representación del santo tenía implicaciones concretas para la plusvalía simbólica que obtenía la aristocracia local de la manipulación ostentosa de dicho objeto.

Recordemos, primeramente, que Santiago había sido el nódulo simbólico del imaginario español de la Reconquista y del espíritu de cruzada peninsular, elementos que luego retomaría en la conquista del Nuevo Mundo. Santiago era, sin duda, el personaje "divino" más adecuado —entre los componentes del panteón cristiano- para ser asociado a la soberanía real en los territorios coloniales. En segundo lugar, a nivel local, debemos recordar lo señalado respecto al imaginario nobiliario, anclado en un supuesto origen guerrero, que era cultivado por la aristocracia chilena, pese a su alejamiento paulatino de la guerra efectiva dejada en manos del ejército profesional de la frontera sur del reino.

pág. 91). Domingo Amunátegui Solar, en El Cabildo de Concepción (1782-1818), Santiago, 1930, pág. 9, señala, para fines del mismo siglo XVIII, que este paseo tenía lugar junto con la procesión realizada durante la fiesta de la Inmaculada Concepción, patrona de la ciudad, el 8 de diciembre. En este caso había una coincidencia con la fecha de refundación urbana, el 8 de diciembre de 1754, después del desplazamiento de su establecimiento original en la bahía de Penco. José Toribio Medina, en su recopilación titulada Cosas de la colonia. Apuntes para la crónica del siglo XVIII en Chile, Santiago, 1952, págs. 24-25, apunta que el paseo del estandarte real en el villorrio de San Martín de la Concha, fundado en 1717 (luego llamado Quillota, en la zona centro-norte de Chile), se llevaba a cabo el día de San Martín, patrón del asentamiento.

26 López Cantos, Angel: Juegos, fiestas y diversiones en la América española, Madrid, 1992, págs. 99-106. 
Este afán de prestigio "nobilizador", esta mentalidad señorial de valores militares, omnipresente en la élite local, se refuerza aún más a nivel simbólico si observamos las imágenes representadas en el propio estandarte: si bien por el anverso están representadas las armas de la monarquía, por el reverso están bordadas las de la ciudad, otorgadas por Carlos V en 1554. ${ }^{27}$ Eran dos caras de la misma medalla, en la que se confundían simbólicamente el poder monárquico y el de la élite local. Se materializaba, así, una identificación visual de la élite con la monarquía y, al mismo tiempo, con el aura nobiliaria que le otorgaba la manipulación privilegiada y monopólica del escudo otorgado a la ciudad, conforme a la ecuación metafórica: "ciudad noble" = cabildo = "nobleza" de Santiago. Ecuación refrendada por la autorización otorgada a la capital chilena, por la misma cédula que designaba dicho escudo, para nominarse "muy noble y muy leal ciudad". ${ }^{28}$

Así, al mismo tiempo que se manifiesta públicamente una "presencia" regular del monarca lejano, alimentando periódicamente su lugar omnipresente en el imaginario colectivo, se le asocia a una fiesta religiosa de gran peso simbólico para la estrategia hispana en América. En este sentido, se trata de una materialización litúrgica que actúa sobre la memoria de la comunidad, recordando la victoria de un sistema de dominación donde se coludían sus tres pilares fundamentales: Monarquía, Iglesia y élite local. Al mismo tiempo, observamos como un hecho central la mencionada plusvalía que obtiene esta última. Primeramente, al asociarse ritualmente a la representación emanada de dicho santo, orientada al refuerzo de su imaginario identitario y de su auto-representación como estamento noble. En segundo lugar, al apropiarse ritualmente del fetiche monárquico y posicionarse como su manipulador oficial, a través de la institución municipal. Así, en 1605, esta última acordaba que en la misa del apóstol el pendón debía ser llevado por el alférez real en posición enhiesta, tanto en la entrada como en la salida de la iglesia, y que fuesen los alcaldes quienes llevasen las borlas de sus extremos. ${ }^{29}$

27 La cédula respectiva, fechada el 10 de mayo de 1554, estipulaba un escudo donde figurara un león con una espada en ristre, rodeado por ocho veneras, símbolos del apóstol Santiago. Cabe señalar que al comienzo del documento oficial vienen diseñadas las armas de la realeza, que pudieron haber servido de modelo para la confección del futuro pendón. Al respecto, véase Medina, José Toribio: Bibliografía de la imprenta en Santiago de Chile desde sus orígenes hasta febrero de 1817, Santiago, 1961, págs. 121-122. También González: "Santiago apóstol...”, págs. 136-137.

28 Ibídem. A propósito de la confusión semántica entre "ciudad" y "cabildo", véase un ejemplo en el acta de 21 de marzo de 1686, ACS, XLII, pág. 121.

29 Acta del cabildo de 23 de julio de 1605, ACS, XXI, págs. 215-216. 
De esta forma, y ya desde mediados del siglo XVI, la liturgia anual del apóstol adquiere rápidamente el objetivo deseado por la monarquía... y por la aristocracia local, que era la encargada oficial de llevarlo y de acompañarlo en estos días.

\section{Posicionamiento de los actores y rol del alférez real}

En efecto, la víspera de la fiesta el cabildo, acompañado del gobernador - si se encontraba en la ciudad—, de la Audiencia y del resto de la élite local, así como de un destacamento de la milicia, iban a casa del alférez real, donde se guardaba el "fetiche", y lo traían con él al edificio municipal. Allí era colgado a la vista pública desde una ventana que diera a la plaza mayor. El edificio que albergaba a la élite institucionalizada se irradiaba, así, a la vista de la población, con la legitimidad otorgada por la presencia y la manipulación directa y exclusiva de este símbolo. Este último, por su parte, comenzaba a "re-cargarse" con la "energía litúrgica" recibida en estos días, reforzando su carácter de encarnación "icónica" del rey lejano al ubicarse en el centro de los eventos y compartir con su cortejo la admiración colectiva brindada al sistema de poder. Luego, todos estos actores se dirigían a la catedral para la celebración de las vísperas respectivas. ${ }^{30}$

Al día siguiente, el mismo cortejo transportaba el pendón en dirección a dicho templo, donde se llevaba a cabo la singular fusión entre la fiesta eminentemente religiosa, la del apóstol Santiago, y la fiesta del "paseo" del estandarte. En la lógica que alimentaba estos eventos, este instante era el más importante, pues dicha fusión se traducía en una verdadera "sacralización" anual del símbolo real. En primer lugar, la misa se efectuaba con la solemnidad de las grandes ocasiones, con el obispo vestido de pontifical, el cabildo eclesiástico en pleno y los representantes de todas las órdenes regulares. ${ }^{31}$ El pendón, por su parte, se colocaba directamente en el interior del

30 Ver por ejemplo, acta del cabildo de 24 de julio de 1649, ACS, XXXIII, págs. 414-415, y acta de 18 de julio de 1698 , ACS, XLIV, pág. 179.

31 Así lo señalaba el monarca en la cédula enviada en 1714 al obispo de Santiago, recordando la importancia de efectuar el paseo del pendón el día de la fiesta de dicho apóstol, “.... asistiendo [tradicionalmente] a este regocijo mis tribunales, las religiones y los prelados vuestros antecesores". BN.Mss, vol. 244, doc. 7113, fjs. 218-219: cédula real de 23 de enero de 1714. Ver también acta del cabildo de 24 de julio de 1656, ACS, XXXV, págs. 195-196, y acta de 22 de julio de 1668, ACS, XXXVII, pág. 277. 
recinto reservado a lo sagrado: el presbiterio. Así, a lo largo de toda la ceremonia, el símbolo real se hallaba a la vista de todos los asistentes en un lugar de gran privilegio, pues se le disponía al lado derecho del altar mayor, que era el lado del evangelio - el de mayor importancia jerárquica, en relación al de la epístola, a la izquierda-, entre éste y el sitial del obispo.

Es interesante destacar, por otra parte, que en dicho espacio sagrado el estandarte no estaba solo. Como en todo evento civil o religioso en que este objeto participaba, la persona encargada de portarlo, el alférez real, estaba a su lado, beneficiándose de la liturgia sacralizante. Y esto, pese a las prohibiciones explícitas que establecían que en el presbiterio no se podían sentar laicos de ninguna condición. ${ }^{32}$ La costumbre había avalado a lo largo del tiempo esta práctica, al punto de hacerla parte indispensable de dicho escenario. De ahí que en el conflicto suscitado entre el obispo Luis Francisco Romero y el cabildo, a comienzos del siglo XVIII, su pretensión de eliminar esta "ilegalidad" no tuviese ningún eco. Por lo demás, el municipio, al conocer la solicitud enviada por el obispo, escribió una perspicaz carta al monarca señalándole que

“[...] aunque esta Santa Iglesia ha franqueado el presbiterio al pendón real, no ha sido por abuso o corruptela de los derechos canónicos, sino por manifestación y lealtad profesada a las armas reales". ${ }^{33}$

Ello explica el hecho de que este instante adquiriera una importancia particular dentro de los objetivos honoríficos que valorizaban dicho cargo municipal, pues era una excepción litúrgica que anualmente lo colocaba en un alto grado de prestigio jerárquico.

La sacralización del fetiche, que lo re-cargaba regularmente de la energía sobrenatural necesaria para ejercer su rol simbólico, se concretaba en el momento oportuno de la ceremonia a través de una bendición explícita realizada por los intermediarios oficiales ante la divinidad, con aspersión de agua bendita y exhortaciones rituales determinadas. A ello se unía el infaltable sermón persuasivo que, sin duda, servía para resaltar el rol jugado por dicho objeto así como su relación con el apóstol hispano. Todo

32 RLI, libr. III, tit. 15, ley XXXIV. Cf. Leal Curiel, Carole: El discurso de la fidelidad. Construcción social del espacio como símbolo del poder regio (Venezuela, siglo XVIII), Caracas, 1990, págs. 134 y $138-139$.

33 Acta del cabildo de 2 de septiembre de 1712, ACS, XLVII, pág. 172. En 1783 se repetiría la misma polémica, ahora entre el obispo de Concepción y la municipalidad de esa ciudad; ver González: "Santiago apóstol...”, págs. 141-143. 
ello recaía también, indirectamente, sobre la persona que lo portaba, es decir, el alférez. ${ }^{34}$

No debe parecer extraño, por lo tanto, el que este personaje asuma un rol cristalizador de las pretensiones políticas de la élite local, al custodiar permanentemente este símbolo, y que por ello mismo no sólo concentre un enorme peso honorífico sino también un rol efectivo en el seno del consejo municipal, donde tenía derecho a voto activo en sus sesiones. Más aún, las disposiciones reales llegaron a otorgarle ciertas preferencias en cuestiones de protocolo, como la precedencia en el asiento, en el voto y en la firma de documentos inmediatamente después de los alcaldes, a los que podía incluso reemplazar en caso de ausencia. ${ }^{35}$

Por lo demás, el quiebre provocado por la inserción de este personaje en el orden jerárquico ocupado por los actores en las ceremonias se presentaba continuamente en toda gran ceremonia o recorrido ritual por el espacio público. Su función institucional y el rol simbólico adscrito al cargo hacían que el notable que lo ocupaba pudiese saltar dicha malla jerárquica y ubicarse en un lugar protagonista en los cortejos de las principales celebraciones. El prestigio personal del "funcionario", renovado pública y frecuentemente con este privilegio, se unía así al derivado de su inseparable ligazón física con el símbolo real. Este "quiebre" de las jerarquías visuales normales se volvía particularmente destacado no sólo, como hemos visto, en la misa del apóstol Santiago, sino también en las cabalgatas que se llevaban a cabo luego de la aclamación de un nuevo monarca y para el paseo anual del estandarte: el alférez real iba siempre al lado del gobernador o del oidor decano que lo reemplazaba. De acuerdo a la ley, en caso de presencia del gobernador - o del virrey, dependiendo del lugar- el alférez ocupaba el lado izquierdo, dejando el derecho - el más importante- a dicho oidor. ${ }^{36}$ En otras oportunidades, se situaba después de la Audiencia, pero en todo caso siempre precediendo a sus pares del cabildo. Este último, por su parte, siempre seguía un orden jerárquico, que comenzaba por el corregidor y los dos alcaldes y continuaba por los regidores en orden de antigüedad.

Dicho rol y, sobre todo, su función política como "defensor" y custodia del estandarte real permitía al cabildo insertarse en la más pura tradi-

34 Ver, por ejemplo, acta del cabildo de 24 de julio de 1631, ACS, XXX, pág. 268, a propósito del conflicto protocolario suscitado entre el obispo y el consejo municipal en torno a las preeminencias rituales del alférez real.

35 Ver, por ejemplo, la cédula enviada a todos los cabildos de América con fecha 11 de abril de 1738, citada en Ayala: Diccionario de gobierno..., I, págs. 170-171. 
ción de los fueros castellanos y compartir institucionalmente el honor y el prestigio de este "funcionario", quien canalizaba la legitimación nobiliaria pretendida por los descendientes de la élite "originaria" de Chile. De hecho, hasta el momento de su venta pública, se trataba de una nominación anual efectuada por los capitulares entre los principales notables de la ciudad. ${ }^{37}$ Esta condición determinaba, efectivamente, que el cargo estuviese en manos de uno de los miembros más importantes de dicha élite, el más "digno" de ocuparse del símbolo real. El prestigio que le atraía dicha ocupación a su persona y a su familia se acrecentaba aún más si consideramos que el alférez no sólo se encargaba de trasladar el fetiche sacralizado para las ocasiones ceremoniales, sino que además lo custodiaba en su propia casa durante todo el año que ocupaba el cargo.

Este gran privilegio alcanzó una proyección geométrica tras la decisión de poner en venta dicha función, a partir de 1612. En ese momento, la custodia del pendón, adscrita al cargo de alférez, pasaba a ser "propiedad" del comprador. En consecuencia, el prestigio emanado de la "posesión" de este objeto, tanto para el personaje mismo como para su familia y su hogar encargado de guardarlo, podía extenderse a perpetuidad y, eventualmente, traspasarse a una nueva generación por la vía de una "venta endogámica". De ahí que en este año de la primera venta "al remate", que lo fue también para otros puestos municipales, sería el cargo de alférez real el más codiciado y el que sería vendido por un precio mucho más alto que los otros. De ahí también el hecho de que surgieran conflictos en el interior de la élite cuando en esa ocasión el cargo fue adquirido por un "hombre nuevo", el capitán Isidoro de Sotomayor, un mercader, sin raíces en la élite originaria de la conquista, la única que se consideraba con la "nobleza" necesaria para monopolizar este puesto privilegiado. ${ }^{38}$ El cabildo llegó incluso a solicitar

36 En las ciudades donde no hubiese una Audiencia, el acompañamiento debía ser encabezado por el gobernador o el corregidor de la municipalidad, cuyo lado derecho debía ser ocupado por el alférez (RLI, libr. III, tit. 15, ley LVI). Para el paseo del pendón en Buenos Aires, por ejemplo, el día de San Martín, una provisión virreinal de 1702 estipulaba que la cabalgata debía ir encabezada por los maceros de la municipalidad, que abrían el paso al gobernador, a cuya derecha iba el alférez real. Ambos eran seguidos por el "cuerpo" del consejo municipal y por una escuadra de soldados; véase Bayle: Los cabildos seculares..., págs. 665-666.

37 Véanse, por ejemplo, las actas del cabildo de 24 de junio de 1568 (ACS, XVII, págs. 236237), de 24 de julio de 1581 (ACS, XVIII, pág. 316) y de 24 de julio de 1582 (ACS, XIX, págs. 39-40).

38 Zúñiga, Jean-Paul: Espagnols d'outre-mer. Émigration, reproduction sociale et mentalités à Santiago-du-Chili au XVIIe siècle, Florencia, tesis de doctorado del Instituto Universitario Europeo, 1995, pág. 420; Góngora, Mario: Encomenderos y estancieros. Estudios acerca de la constitución social aristocrática de Chile después de la conquista, 1580-1660, Santiago, 1970, pág. 78. 
a la Audiencia que anulase la venta, proponiendo que fuese el propio municipio quien eligiese al nuevo alférez, y prometiendo restituir el precio que se había convenido en el remate. ${ }^{39}$

\section{El ritual cívico luego de la misa mayor}

Volviendo a la fiesta del apóstol Santiago, debemos recordar también que este juego de energías legitimantes que circulaba de ida y de vuelta entre el estandarte real y los actores locales del poder, pasando por la sacralización eclesiástica, se reforzaba aún más en la procesión religiosa que seguía a la misa. Como era de esperar, allí desfilaban, en primer plano, el alférez portando el símbolo y los dos alcaldes asidos de sus borlas laterales. Más aún, las propias andas de la imagen del santo eran portadas en ese momento por regidores del municipio, junto con miembros del cabildo catedralicio.

En fin, el espacio público continuaba siendo el escenario de la nueva etapa ritual que seguía a las ceremonias religiosas. Se procedía entonces al "paseo" oficial que determinaba la ley y la costumbre. En realidad, se trataba del mismo rito lúdico-profano que acompañaba la proclamación de un nuevo soberano : el pendón real, siempre en las manos de su alférez, encabezaba una ostentosa cabalgata de las autoridades vicarias del monarca y del conjunto de la aristocracia por las principales calles de la ciudad. Como en dichas grandes ocasiones, las descargas de armas de fuego y el ruido de tambores y pífanos de la milicia, así como de las campanas de las iglesias, acrecentaban también la espectacularidad del evento.

Vista la importancia trascendental que había adquirido la liturgia religiosa, este momento aparecía en realidad como un acto complementario. Su función se orientaba más bien a reforzar $a$ posteriori y en la vía pública la sacralización que había obtenido el objeto en el momento de la ceremonia canónica. Además, esta cabalgata ayudaba a reforzar la "ganancia simbólica" que estaban obteniendo los grupos dominantes, por la evidente

39 Sin embargo, Sotomayor sería confirmado en su cargo por el rey, cinco años más tarde. Archivo General de Indias, Chile, 27: carta del cabildo al rey de 19 de diciembre de 1613, citada por Meza Villalobos, Nestor: La conciencia política chilena durante la Monarquía, Santiago, 1958, pág. 72, y González: "Santiago apóstol...”, pág. 138. En 1681, después de la muerte del alférez del momento, fue el gobernador mismo quien nombró al sucesor, en premio de una donación de 400 pesos que esta persona había hecho al tesoro real (Acta del cabildo de 24 de diciembre de 1681, ACS, XLI, págs. 95-98). 
admiración colectiva que generaba su lucimiento público y por el hecho de tener el privilegio de acompañar al fetiche sacralizado. Como apuntaba el cronista Felipe Gómez de Vidaurre,

"Es verdaderamente ésta la función que da más gusto y que presenta la idea más clara de sus genios [de los criollos], porque no sólo se ve esta riqueza en los que van en la función, que son todos los cabildantes, algunos parientes y amigos del alférez real y otros que por gusto salen acompañando el Pabellón Real, sino en el inmenso pueblo que concurre a la plaza, todo de gala, a ver esta función". ${ }^{40}$

Por lo demás, la cabalgata en sí misma, en el contexto de Santiago colonial, constituía un recordatorio ritual de todo ese universo de raíces guerrero-señoriales que la élite de la ciudad reivindicaba e intentaba reproducir en torno a cada liturgia del poder.

En ese mismo plano podemos situar la importancia que se le otorgaba a la reproducción de la tradición hispana y virreinal de efectuar corridas de toros para clausurar la celebración. Al igual que para otras ocasiones festivas, el cabildo se esforzaba cada año para organizar tres días de fiestas profanas, si bien hay períodos en que al parecer esta práctica cae en el olvido, hasta que alguna revisión de archivos o el entusiasmo de algún celoso regidor hacen que se recomience la tradición importada desde la Península. En ocasiones, las corridas podían incluir también torneos y juegos ecuestres de origen medieval, tan caros a la élite colonial por su identificación con los patrones lúdicos identitarios de la nobleza española. ${ }^{41}$

Verdaderos "juegos escénicos", dichas expresiones lúdicas fueron desde un comienzo adaptadas y reproducidas en América como otro canal privilegiado para hacer circular visualmente un mensaje reforzador del orden social, un instrumento que se adicionaba al ceremonial grave, a través de la aparente ingenuidad del universo lúdico, a fin de regenerar en ese plano el prestigio de los actores del poder, particularmente de la élite. Son diversiones "señoriales", monopolizadas por la élite local.

Más aún, estas diversiones no sólo expresaban una visión aristocrática del mundo, sino también una visión guerrera, tanto se imbricaban ambas en el imaginario de los grupos dominantes. ${ }^{42}$ Sin ir más lejos, al organizar

40 Gómez de Vidaurre, Felipe: Historia geográfica, natural y civil del reino de Chile, $\mathrm{CHCh}$, $\mathrm{XV}$, pág. 305.

41 Ver, como ejemplo, las actas del cabildo de 7 de noviembre de 1665 y de 5 de octubre de 1666, ACS, XXXVII, págs. 73-74 y 128-129, y el acta de 27 de julio de 1691, ACS, XLII, págs. 400-401.

42 Viqueira, Juan Pedro: ¿Relajados o reprimidos? Diversiones públicas y vida social en la ciudad de México durante el Siglo de las Luces, México, 1987, págs. 33-36. 
las manifestaciones para la fiesta del apóstol Santiago de 1651, el cabildo señalaba explícitamente que los toros y cañas debían ejecutarse "con capas y espadas"; una clara alusión, pensamos, a la nobleza principal de España, que era justamente "de capa y espada". ${ }^{43}$ Dichas expresiones lúdicas contribuían directamente, así, a alimentar el conjunto del universo identitario de las élites chilenas. De hecho, conforme a la propia tradición española, la corrida, “...école de guerre, jeu d'un pays installé dans la guerre, où domine l'élevage extensif...", ${ }^{44}$ se había insertado cómodamente en el contexto de la Conquista, apoyando el imaginario bélico ennoblecedor de las nuevas "aristocracias" coloniales.

La significación socio-política asignada a estos espectáculos explica, efectivamente, el interés de la élite de Santiago por organizarlos cada vez que una ocasión especial merecería una celebración, incluyéndolos, como era la tradición hispana, en las grandes festividades del calendario eclesiástico. Un ejemplo claro de esta proyección se puede ver en el caso de la fiesta anual que vemos asociada al estandarte real. En tanto que evento regular y frecuente en el tiempo y en tanto que articulación ritual de referentes simbólicos pluridireccionales - fiesta de un santo guerrero por excelencia, fiesta del símbolo real y fiesta, al mismo tiempo, de la "ciudad"/élite institucionalizada-, no nos debe extrañar que dicho día fuese una ocasión preferente para la organización de corridas y de juegos "señoriales" en la plaza principal. De hecho, visto el rol central que asumía en ese día el alférez real, era evidente y lógico que se encontrara en primera línea en esta etapa de la celebración, generalmente encabezando una de las cuadrillas. ${ }^{45}$

43 Acta del cabildo de 12 de septiembre de 1651, ACS, XXXIV, pág. 167.

44 Chaunu, Pierre: L'Espagne de Charles Quint, Paris, 1973, II, pág. 570.

45 Véase, por ejemplo, el acta del cabildo de 11 de julio de 1608, ACS, XXIV, pág. 94. Hacia 1592 encontramos por primera vez una referencia a los juegos de cañas ligados a la celebración del apóstol Santiago. Sin embargo, el mismo documento informa que esta era una costumbre habitual, pues “... siempre se suele solemnizar con hacer juego de cañas y correr toros otro día después" (Acta del cabildo de 10 de julio de 1592, ACS, XX, pág. 386). Ver González: “Santiago apóstol...”, pág. 137, donde se señala, erróneamente, que ésta habría sido la primera vez que se habrían organizado tales juegos para celebrar a dicho santo. 


\title{
Anexo
}

\section{RECEPCIÓN DEL SELLO REAL CON MOTIVO DEL ESTABLECIMIENTO DE la Real Audiencia en Santiago (1609) ${ }^{46}$}

\begin{abstract}
"Yo Melchor Fernandez de la Serna escribano del Rey n[uest]ro. Señor é mayor de gobernacion en este Reyno certifico y doi fé á todos los que la presente vieren como lune[s] siete dias del mes de setiembre de mil y seiscientos nueve años como á la hora de las tres de la tarde poco mas ó menos, estando su señoria el Señor Alonso Garcia Ramon presidente de la Real Audiencia que el Rey n[uest]ro. Señor manda fundar en esta d[ic]ha. prov[inci] en la d[ic] ha. casa de el lic[encia] ${ }^{\text {do }}$ Fran[cis $]^{\text {co }}$ Pastene que es cerca de la d[ic]ha. ciudad, los Señores Doctor Luis Merlo de la Fuente y licenciados Fran[cis] ${ }^{\text {co }}$ Talaberano Gallegos y Juan Cajal y doctor Gabriel de Celada á caballo acompañados de todos los caballeros é jente principal de la ciudad con grande concurso de todos los vecinos y moradores de ella á la hora de $\mathrm{d}[\mathrm{ic}] \mathrm{ha}$. fueron á la d[ic]ha. casa y de allí todos juntos estuvieron acompañando á el d[ic]ho. S[eño]r. presidente el cual en una banda de tafetan trujo puesto al pecho el real sello metido en una cajita pequeña de hierro dorada y habiendo su señoria, los d[ic]hos. S[eño]res. oidores y todo el d[ic]ho. acompañamiento llegado al monasterio del S[eño]r. San Fran[cis $]^{\mathrm{co}}$ que es fuera de la d[ic]ha. ciudad y junto á ella hallaron aderesada una grande pieza con paños de seda y su docel y debajo del fecha una pevína de casi vara de alto y dos gradas, cubierto todo con una alfombra grande turqueza y encima [de] la d[ic]ha. tarima un bufete con su tapete de seda y tela y encima dos cojines de terciopelo carmesí uno sobre otro y llegado los dichos Señores y acompañamiento á la d[ic]ha. pieza, el d[ic]ho. $\mathrm{S}[\mathrm{eño}] \mathrm{r}$. presidente y el S[eño]r. doctor Luis Merlo de la Fuente subieron á lo alto de la d[ic]ha. tarima y descubiertos é incados de rodillas el dicho S[eño]r. presidente puso el $\mathrm{d}[\mathrm{ic}]$ ho. cofresito de hierro dorado en que iba el d[ic]ho. real sello ensima de los d[ic]hos. dos cojines de terciopelo y el d[ic]ho. Señor doctor Luis Merlo de la Fuente, lo cubrió á el d[ic]ho. cofresito y cojines con un paño de tafetan rosado, cuajado de muchas flores de seda de todos colores y fecho, el d[ic]ho. Señor presidente, señores oidores con el demás acompañamiento salieron del $\mathrm{d}[\mathrm{ic}]$ ho. monasterio quedando el en la d[ic]ha. pieza el d[ic]ho. Señor doctor Luis Merlo de la Fuente, acompañando yo el presente secretario á su m[erce]d. por guarda y custodia del $\mathrm{d}[\mathrm{ic}]$ ho. real sello y en la forma $\mathrm{d}[\mathrm{ic}]$ ha. se estuvo su merced
\end{abstract}

46 Gay, Claudio: Historia física y política de Chile. Documentos sobre la historia, la estadística y la geografía, París, 1852, II, págs. 189-193. 
asistiendo á la d[ic]ha. guardia teniendole así mismo de una de las compañias de infanteria de esta ciudad que fue la del capitan Gines de Lillo. Los arcabuceros de la Real asistieron, ejercieron su guardia á la puerta de la iglesia del d[ic]ho. monasterio y los alabarderos a la puerta de la piesa donde estaba el d[ic]ho. real sello y ensima de la cajita en que estaba el d[ic]ho. real sello, estuvo puesta una corona de plata dorada con unas piedras engastadas á la redonda y el martes luego siguiente día de Natividad de N[ues]tra. S[eño]ra. á hora de las cuatro, desde las casas reales á donde se juntaron el S[eño]r. presidente y los S[eño]res. oidores, religiosos, obispo, los alcaldes y regidores y demas personas del cab[ild] ${ }^{\circ}$ vestidos con sus ropas rosagantes y gorras de razo carmesí, con los demás caballeros y gente de la ciudad, prelados y religiosos de las órdenes y cleresía en grande concurso de gente, vinieron al d[ic]ho. monasterio a donde el d[ic]ho. S[eño]r. doctor Luis Merlo de la Fuente estava y entrando los que cupieron en la piesa donde estava el d[ic]ho. real sello, el d[ic]ho. S[eño]r. presidente y S[eño]r. D[octo] $]^{\mathrm{r}}$ Merlo subieron las dos gradas é incados de rodillas delante del bufete, el d[ic]ho. S[eño]r. D[octo] Merlo con la llave que tenia habrió el d[ic]ho. cofresito dorado y le saco envuelto en un tafetan rosado matisado de seda de diferentes colores y lo puso ensima de los dos cojines de terciopelo, de adonde el d[ic]ho. S[eño]r. presidente le tomó con el d[ic]ho. tafetan y con la reverencia debida le besó y puso sobre su cabeza y le volvió a poner sobre el d[ic]ho. tafetan y cojines y luego hizo la misma ceremonia el Señor obispo de esta ciudad de Sant[iag $]^{\circ}$ D[on]. Frai Juan Perez de Espinosa y luego hicieron lo mismo los S[eño]res. oidores y luego los alcaldes hordinarios y el d[ic]ho. Señor doctor Merlo tornó á envolver del d[ic]ho. tafetan del real sello y lo volvió á poner en el d[ic]ho. cofresito y lo serró y el d[ic]ho. S[eño]r. presidente y su merced le bajaron en las manos y yendo á la derecha el d[ic]ho. S[eño]r. presidente y llevandole así llegados á la puerta de la reja de la capilla mayor del $\mathrm{S}[\mathrm{eño}] \mathrm{r}$. San Fran[cis] ${ }^{\mathrm{co}}$ entraron con él debajo del palio que para ello se hizo de razo carmesí con las senefas de terciopelo y guarnecido por la parte de afuera con flocadura grande de oro y por la de adentro con otra flocadura del mismo tamaño de plata el cual llevaron los dos alcaldes hordinarios y once personas del cab[ild] ${ }^{\circ}$ que por todos fueron trece vestidos todos con las ropas rosagantes $\mathrm{d}$ [ic]has. y saliendo á la puerta de la iglesia hallaron fuera de ella un caballo obero aderezado con gualdrapa y guarniciones de terciopelo negro todo muy bien guarnecido cubierto con sutellis, el cual habia ido desde las casas reales con todo el d[ic]ho. acompañamiento y los $\mathrm{d}[\mathrm{ic}]$ hos. S[eño]res. presidente y doctor Merlo pusieron el $\mathrm{d}[\mathrm{ic}]$ ho. cofresito del real sello ensima de la silla del d[ic]ho. caballo y lo cubrieron con una banda de tafetan rosado guarnecida de plata y luego pusieron ensima la otra de tafetan rosado matisado de diferentes seda y plata que con la que habia estado cubierto sobre el bufete y teniendo los d[ic]hos. señores con sus manos la dicha banda y cofresito yendo el $\mathrm{d}[\mathrm{ic}]$ ho. $\mathrm{S}[\mathrm{eño}] \mathrm{r}$. presidente á la mano derecha y el d[ic]ho. S[eño]r. doctor Merlo á la izquierda, yendo el d[ic]ho. real sello debajo del $\mathrm{d}[\mathrm{ic}]$ ho. palio y quedandose la cruz y religiosos que salieron rebestidos del 


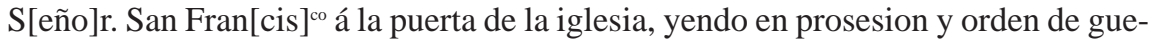
rra, se fue marchando hasta llegar á las casas reales, yendo acompañado el d[ic]ho. real sello de grande infinidad de gente, eclesiasticos religiosos y seglares en que fueron cinco capitanías las tres de ellas de gente de acaballo, capitanes, el coronel Pedro Cortes, Don Diego Flores y D[on]. Pedro de la Barrera y dos de infanteria capitanes Gines de Lillo y Antonio Recio y salió tambien el estandarte de la ciudad el cual llebó D[on]. Diego de Godoi y los S[eño]res. licen[cia] ${ }^{\text {dos }}$ Talaverano y Juan de Cajal llevaron de diestro el caballo en que iba el d[ic]ho. real sello, yendo cada uno á su lado, hacidos de una banda cada uno de tafetan carmesí guarnecida de plata y en muy buena órden y disparando mucha arcabuceria y con muchas cajas, trompetas y pifanos llegaron á la plaza de la $\mathrm{d}[\mathrm{ic}] \mathrm{ha}$. ciudad que es grande de una cuadra entera, la cual y las calles estubieron muy bien aderesadas, y habiendo la caballeria tomado cuatro puestos que son las calles de las esquinas de la $\mathrm{d}[\mathrm{ic}]$ ha. plaza, que la infanteria y demás acompañamiento dando vuelta en prosesion á toda la d[ic]ha. Real casa y ultimamente despues de dada la d[ic]ha. vuelta toda la infanteria se fué poniendo en dos tropas habriendo una calle ancha y por enmedio de ella fué entrando el real sello hasta llegar á la puerta de las escaleras de las dichas casas que salen á la plaza y habiendo tomado en sus manos el d[ic]ho. $\mathrm{S}[\mathrm{eño}] \mathrm{r}$. presidente y d[ic]ho. doctor Merlo el cofresito del dicho real sello cubierto con el d[ic]ho. tafetan lo subieron á la Real sala de la d[ic]ha. Real Audiencia y lo pusieron sobre dos cojines de terciopelo carmesí que estaban puestos ensima de un bufete cubierto con un tapete de terciopelo carmesí con flecadura de oro que estava en lo alto de las gradas y debajo del docel de la d[ic]ha. audiencia y estando todos en pié y descubiertos, el d[ic]ho. Señor doctor Merlo con la llave que tenia y habia traido al cuello, abrió el d[ic]ho. cofresito y sacó el d[ic]ho. real sello y lo puso sobre [...espacio en blanco...] y cojines y estando allí el d[ic]ho. S[eño]r. presidente y S[eño]res. oidores asistiendo el S[eño]r. obispo, hicieron todos la misma seremonia que habian $\mathrm{f}[\mathrm{ec}]$ ho. en San Fran $[\mathrm{cis}]^{\text {co }}$ besandolo y poniendolo sobre sus cabezas, y luego el d[ic]ho. S[eño]r. presidente dijo á los d[ic]hos. S[eño]res. oidores como S[u]. M[agestad]. el Rey n[uest]ro. Señor le habia fecho merced de proveerle por su presidente de la d[ic]ha. real audiencia que pedia se obedeciese y cumpliese y habiendo tomado el $\mathrm{d}[\mathrm{ic}]$ ho. S[eño]r. doctor Merlo de mano del $\mathrm{d}[\mathrm{ic}]$ ho. S[eño]r. presidente el d[ic]ho. real titulo me lo dio á mi el pres[en $]^{\text {te }}$ secretario y por mandado de su merced y de los demás S[eño]res. oidores lo lei de berbo ad berbum y leido los d[ic]hos. S[eño]res. mandaron que el d[ic]ho. S[eño]r. presidente hiciese el juramento que S[u]. M[agestad]. mandaba y debia hacer por razon del $\mathrm{d}[\mathrm{ic}]$ ho. oficio para que habiendolo fecho aprehendiese su posecion y $\mathrm{S}[\mathrm{u}]$. Señoria dijo que estava presto de cumplir lo que S[u]. M[agestad]. le mandaba debia hacer y en su cumplimiento se incó de rodillas sobre un cojin de terciopelo que estava puesto al lado derecho del $\mathrm{d}[$ ic] ho. bufete y puesta la mano derecha sobre el d[ic]ho. real sello, hizo el d[ic]ho. juramento que le dió escrito el d[ic]ho. Señor Doctor Merlo y fecho se asentó, en los estrados reales de la d[ic]ha. 
audiencia enmedio del d[ic]ho. docel, y á su mano izquierda el d[ic]ho. S[eño]r. obispo que hasta entonces habia estado en pié como los demás y luego el d[ic]ho. S[eño]r. Doctor Merlo hizo el mismo pedimento juram[en $]^{\text {to }}$ y solemnidad y habiendo abrazado á los d[ic]hos. S[eño]res. se asentó á la mano derecha del $\mathrm{d}[\mathrm{ic}]$ ho. Señor presidente y los otros d[ic]hos. tres S[eño]res. oidores por su turno fueron haciendo lo mismo y acabado este acto del resibimiento de todos y habiendo el S[eño]r. presidente dado gracias á n[uest]ro. Señor por cuan bien se habia fecho todo, mando que el real sello se llevase á su cuarto hasta que se ordenase la parte y lugar conveniente adonde se hubiese de poner, el cual fueron acompañando todos los caballeros y demás personas que estavan en la dicha real sala y los d[ic]hos. señores salieron de la sala real a el corredor que esta delante de ella y cae á la plaza en la cual estavan las compañias d[ic]has. de a caballo y de infanteria las de a caballo en los puestos d[ic]hos. esquinas de la plaza y las de infanteria en dos puestos enfrente la una de la otra, de las cuales salieron diferentes mangas escaramusando unas con otras y las compañías de acaballo escaramusaron tambien y con esto se acabó la fiesta de este recibimiento la cual doi fee que se hizo con grandisima solemnidad y aplauso de toda esta ciudad e para que á todos conste de mandato del d[ic]ho. Señor Doctor Merlo doi esta fee fecha en Santiago de Chile en nueve dias del mes de Setiembre del año de mil y seiscientos y nueve.- firmolo el d[ic]ho. S[eño]r. Doctor". 